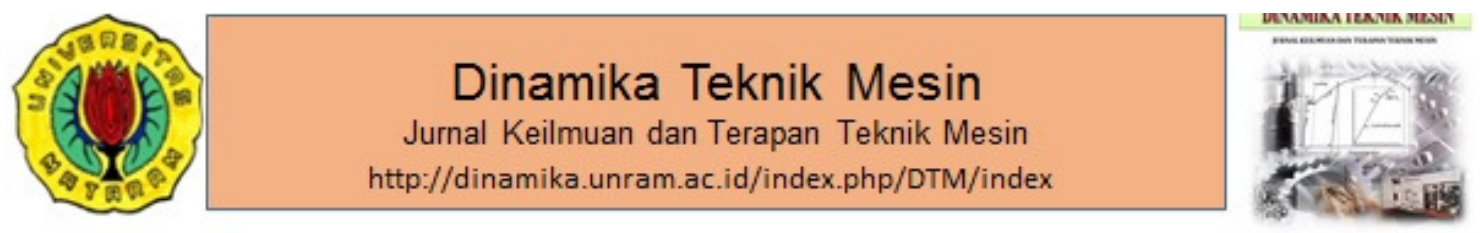

\title{
Adsorbsi gas karbon dioksida dalam biogas dengan menggunakan endapan batu kapur
}

\section{Adsorption of carbon dioxide $\left(\mathrm{CO}_{2}\right)$ in biogas using $\mathrm{Ca}(\mathrm{OH})_{2}$}

\author{
R. Sutanto", A. Mulyanto, M. Wirawan, I.B. Alit, N. Nurchayati \\ Jurusan Teknik Mesin Fakultas Teknik Universitas Mataram Jl. Majapahit No.62 Mataram NTB \\ *Email : r.sutanto@unram.ac.id
}

\begin{abstract}
ARTICLE INFO ABSTRACT
Article History:

Received 12 February 2019

Accepted 8 March 2019

Available online 1 July 2019

Keywords:

Biogas

Adsorption

carbon dioxide

Calcium hydroxide

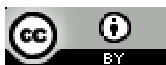

With the depleting reserves of energy sources and fuel shortages that occur in Indonesia today, it is needed a cheap alternative energy sources and environmentally friendly, one of which is biogas. In this study biogas is generated from horse manure. The fermentation of horse manure can produce biogas with the largest component of the $\mathrm{CH}_{4}(49.5 \%)$ and $\mathrm{CO}_{2}(49.7 \%)$. The use of biogas as a fuel is still in the household scale and has not been used optimally. This is due to the biogas still containing high levels of $\mathrm{CO}_{2}$ so that it has low value of heat is produced. This research reduces the $\mathrm{CO}_{2}$ levels by using the $\mathrm{Ca}(\mathrm{OH})_{2}$ or limestone sedimentary, and then react with the $\mathrm{CO}_{2}$ to form $\mathrm{CaCO}_{3}$ and $\mathrm{H}_{2} \mathrm{O}$. The variables studied are the influence of the flow rate of the biogas that $\mathrm{CO}_{2}$ absorbed and $\mathrm{CH}_{4} \cdot \mathrm{CO}_{2}$ absorption made by passing the biogas with a variety of flow rates in the $\mathrm{Ca}(\mathrm{OH})_{2}$ at a certain concentration. Gas and $\mathrm{Ca}(\mathrm{OH})_{2}$ contact each other and the chemical reaction occurs. Every 2 minute interval of gas coming out of the absorber is detected by a biogas tester for analysis of absorbed $\mathrm{CO} 2$ and $\mathrm{CH} 4$ produced. The research results show that the average $\mathrm{CO}_{2}$ can be absorbed at all the variations of biogas flow rate (5 liter/min. 10 liter/min and 15 liter/min) produced $\mathrm{CH}_{4}$ at the biogas flow rate of 10 liter/min is $91 \%$, then at the flow rate of $5 \mathrm{liter} / \mathrm{min}$ is $76.2 \%$ and at the flow rate of 15 liter/min is $72 \%$.
\end{abstract}

\section{PENDAHULUAN}

Semakin menipisnya cadangan minyak bumi serta harga minyak mentah dunia yang semakin tinggi, maka penemuan dan pengembangan energi alternatif yang ramah lingkungan perlu segera dilakukan. Satu diantara energi alternatif ramah lingkungan yang saat ini sedang dalam pengembangan adalah energi yang berasal dari bahan-bahan organik, hal ini dimungkinkan karena bahan tersebut tergolong energi yang dapat diperbarui dan ramah lingkungan, Sutanto dkk. (2014). Keberadaaan bahan tersebut mudah diperoleh dan terjamin keberlanjutannya, dan yang paling penting bahan tersebut ramah terhadap lingkungan, Sutanto dkk. (2014). Hal inilah yang menjadi pertimbangan utama dimana bahan organik dipakai sebagai energi masa depan sebagai upaya 
mewujudkan teknologi hijau (green technology). Biogas adalah satu diantara produk teknologi hijau yang sedang dikembangkan dalam dua dekade terakhir. Hal ini dikarenakan gas yang dihasilkan dari proses fermentasi memiliki kemampuan dalam menghasilkan gas seperti $\mathrm{CH}_{4}, \mathrm{CO}_{2}, \mathrm{H}_{2} \mathrm{~S}, \mathrm{H}_{2} \mathrm{O}$ dan gas lain, Sutanto dkk. (2014). Dalam hal ini tentunya yang dimanfaatkan hanyalah gas metana $\left(\mathrm{CH}_{4}\right)$, karena $\mathrm{CH}_{4}$ memiliki nilai kalor yang cukup tinggi sehingga dapat dimanfaatkan sebagai alternatif bahan bakar.

Kotoran kuda untuk saat masih belum termanfaatkan secara maksimal oleh petani. Hal terlihat dari masih banyaknya kotoran yang menumpuk disebelah kandang bahkan ada sebagian yang dibuang begitu saja ke sungai. Akibatnya banyak persoalan muncul yang disebabkan oleh kotoran ternak seperti sungai menjadi dangkal, merusak pemandangan dan bau yang tidak sedap. Pada saat musim hujan kotoran tersebut akan terbawa oleh air hujan yang mengalir kedaerah yang lebih rendah, sehingga kuman yang ada di kotoran tadi akan menjadi penyebab masuknya bibit penyakit. Untuk mengurangi dampak lingkungan yang disebabkan oleh limbah kotoran kuda maka alternatif yang bisa ditempuh yakni dengan memanfaatkan kotoran tersebut menjadi biogas. Kotoran kuda menjadi prioritas utama untuk digunakan sebagai bahan baku pembuatan biogas dengan pertimbangan diantaranya mudah didapat, terjamin kontinuitasnya dan dapat mencegah pencemaran lingkungan maupun air tanah. Biogas yang dihasilkan secara langsung dari digester belum bisa digunakan secara langsung karena gas yang dihasilkan masih banyak mengandung pengotor yang merugikan diantaranya $\mathrm{CO}_{2}$ dan $\mathrm{H}_{2} \mathrm{~S}$. Gas $\mathrm{H}_{2} \mathrm{~S}$ bersifat reaktif sehingga jika bersentuhan dengan logam akan menimbulkan korosi. Sedangkan gas $\mathrm{CO}_{2}$ dalam biogas perlu dimurnikan atau diserap karena gas tersebut dapat menurunkan nilai kalor pembakaran bahan bakar, Sutanto dkk.(2014).

Harasimowicz dkk. (2007) nilai kalor pembakaran gas metana murni pada tekanan $1 \mathrm{~atm}$ dan temperatur $15,5{ }^{\circ} \mathrm{C}$ yaitu $9100 \mathrm{kkal} / \mathrm{m}^{3}(12.740 \mathrm{kkal} / \mathrm{kg})$. Sedangkan nilai kalor pembakaran biogas sekitar $4.800-6.900 \mathrm{kkal} / \mathrm{m}^{3}(6.720-9660 \mathrm{kkal} / \mathrm{kg})$. Tingginya kadar $\mathrm{CO}_{2}$ dalam biogas menyebabkan nilai kalor pembakaran turun menjadi sebesar 4301,63-6213,47 kkal/ $\mathrm{m}^{3}(6022,28$ $8698,85 \mathrm{kkal} / \mathrm{kg})$ dari nilai pembakaran $\mathrm{CH}_{4}$ murni sebasar $9559,18 \mathrm{kkal} / \mathrm{m}^{3}(13382,85 \mathrm{kkal} / \mathrm{kg})$.

Apriyanti (2012) bahwa pemurnian biogas dari $\mathrm{CO}_{2}$ dengan menggunakan zeolit. Zeolit zeochem 4A dapat menyerap gas $\mathrm{CO}_{2}$ sebanyak $18,70 \%$. Proses penyerapan gas $\mathrm{CO}_{2}$ dalam biogas dipengaruhi oleh jenis, ukuran, partikel, ukuran pori, jumlah zeolit, serta bentuk dan ukuran kolom.

Listyowati dkk. (2012) memanfaatkan zeolit alam untuk memurnikan biogas dari pengotor $\mathrm{CO}_{2}$ dan $\mathrm{H}_{2} \mathrm{~S}$. Prosentase kadar $\mathrm{CO}_{2}$ dan $\mathrm{H}_{2} \mathrm{~S}$ yang berhasil disisihkan maksimal sebesar $87,041 \%$ dan $64,977 \%$. Akibat pemurnian ini maka kandungan $\mathrm{CH}_{4}$ dalam biogas meningkat sebesar $37,375 \%$ setelah dimurnikan.

Alwathan dkk. (2013) melakukan pemurnian biogas dari hasil pengolahan limbah cair rumah sakit dengan menggunakan karbon aktif dalam berbagai ukuran dan waktu pengaliran, dengan hasil terbaik adalah adsorben berukuran 14 mesh dapat menyerap $368,65 \mathrm{mg} \mathrm{H}_{2} \mathrm{~S}$ dalam waktu 90 menit.

Widyastuti dkk. (2013) memurnikan biogas dari unsur pengotor $\mathrm{CO}_{2}$ dengan memakai karbon aktif yang berasal dari cangkang sawit, kemudian dibandingkan dengan karbon aktif komersial. Prosentase peningkatan kadar $\mathrm{CH}_{4}$ sebesar $7 \%$ dan prosentase penurunan kadar $\mathrm{CO}_{2}$ sebesar $6,1 \%$ dengan menggunakan karbon aktif dari cangkang kelapa sawit, sedangkan karbon aktif komersial meningkatkan kadar $\mathrm{CH}_{4}$ sebesar $11,5 \%$ dan menurunkan kadar $\mathrm{CO}_{2}$ sebesar $12,9 \%$.

Denny dkk. (2014) melakukan pemurnian biogas dengan menggunakan metode bertingkat dimana zeolit pemurnian pertama dan arang aktif pada pemurnian kedua. Pada penelitian ini difokuskan pada pengamatan adsorben zeolit alam, ukuran zeolit halus dan kasar, dan variasi massa zeolit adalah 50 gram, 100 gram dan 150 gram. Dalam 60 menit, hasil terbaik diperoleh ukuran zeolit yang halus dengan massa 150 gram yakni diperoleh $\mathrm{CO}_{2}$ turun menjadi $4,07 \%$, namun tekanan turun menjadi $0,65 \mathrm{kPa}$. Sedangkan untuk ukuran zeolit kasar diperoleh $\mathrm{CO}_{2}$ sebesar $4,26 \%$, dengan penurunan tekanan $0,84 \mathrm{kPa}$.

Naqiibatin dan Triwikantoro, 2014, dalam penelitianya menggunakan larutan $\mathrm{Ca}(\mathrm{OH})_{2}$ untuk memurnikan biogas. Pemurnian biogas dilakukan dengan menggunakan variasi konsentrasi absorben yaitu larutan $\mathrm{Ca}(\mathrm{OH})_{2} 0.1,1.5$, dan $2.5 \mathrm{M}$. hasil uji kromatografi gas menunjukan gas setelah difilter adalah $100 \%$ area, sedangkan sebelum dimurnikan terdapat gas metana sebesar $82.46 \%$ area.

Selama ini proses pemurnian biogas banyak menggunakan bahan kimia baik berupa padatan maupun cairan seperti silika, alumina, karbon aktif atau silikat, $\mathrm{NaOH}, \mathrm{Fe}_{2} \mathrm{O}_{3}$ dan masih banyak yang lain. Penggunaan bahan kimia seperti tersebut diatas bagi masyarakat pengguna terutama masyarakat pedesaan masih terasa asing di telinga mereka dan sulit mereka dapatkan. Penggunaan bahan alam yang ramah lingkungan dalam pemurniaan biogas belum banyak diteliti. Salah satu bahan alam yang ramah lingkungan adalah batu kapur, disamping keberadaannya yang melimpah juga ditelinga masyarakat pengguna tidak asing lagi. Sebelum digunakan sebagai adsorben, batu 
kapur mengalami proses pretreatment terlebih dahulu yakni dengan menambahkan air sampai membentuk pasta atau endapan batu kapur. Endapan batu kapur tersebut selanjutnya digunakan sebagai adsorben untuk mengikat $\mathrm{CO}_{2}$ dalam bogas. Penelitian yang dilakukan ini bertujuan untuk mengetahui perbandingan kandungan $\mathrm{CO}_{2}$ dan $\mathrm{CH}_{4}$ dalam biogas sebelum dimurnikan dan setelah dimurnikan dan untuk mempelajari efektivitas pemakaian endapan batu kapur dalam menurunkan kadar $\mathrm{CO}_{2}$.

\section{METODE PENELITIAN}

Metode yang dipakai untuk mencapai tujuan penelitian yaitu melakukan beberapa tahap percobaan : tahap pertama adalah menganalisa komposisi awal yang terdapat dalam biogas untuk mengetahui konsentrasi awal gas $\mathrm{CO}_{2}$ dan konsentrasi awal gas $\mathrm{CH}_{4}$ yang ada dalam biogas. Tahap kedua adalah melakukan pengujian terhadap kemampuan media slurry $\mathrm{Ca}(\mathrm{OH})_{2}$ atau endapan batu kapur dalam mengikat gas $\mathrm{CO}_{2}$ dalam unsur biogas sehingga akan menaikkan kualiatas biogas.

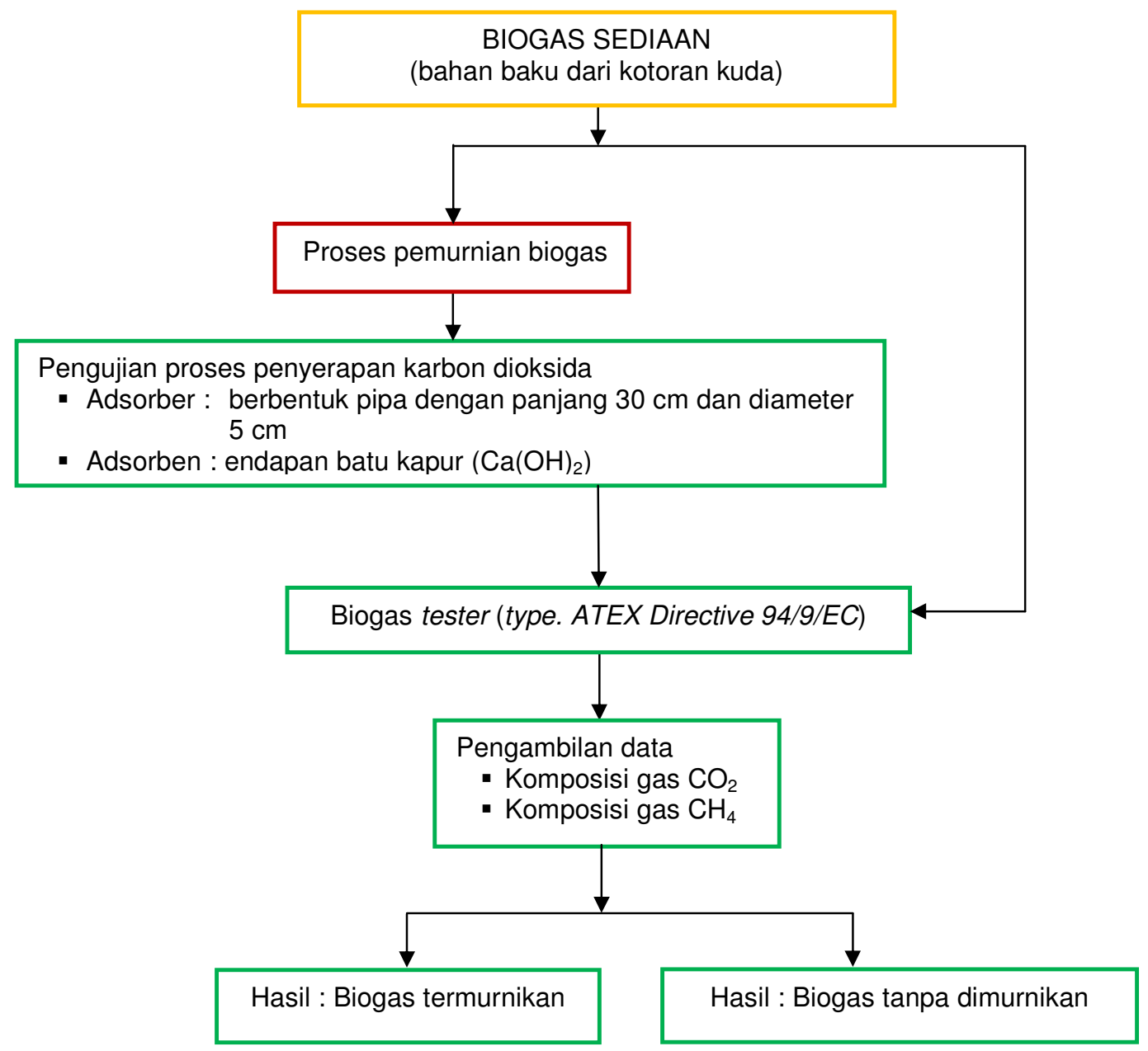

Gambar 1. Skema diagram alir penelitian

Bahan utama yang dibutuhkan dalam penelitian ini adalah kotoran ternak (kuda), selanjutnya campuran kotoran kuda dan air dengan perbandingan 1 : 1 diaduk sampai larut. Campuran tersebut dimasukkan ke dalam tangki penampung (digester). Kemudian semua saluran dan lubang ditutup agar tidak ada udara yang masuk ke dalam sistem. Selanjutnya, campuran kotoran dengan air didiamkan selama $\pm 3-4$ minggu sehingga terbentuk biogas. Selanjutnya untuk adsorber digunakan $\mathrm{Ca}(\mathrm{OH})_{2}$ dengan memakai perbandingan campuran bahan pemurni yakni 778 gr $\mathrm{CaO}$ dengan $250 \mathrm{gr}$ $\mathrm{H}_{2} \mathrm{O}$ lalu keduanya dicampur menjadi $\mathrm{Ca}(\mathrm{OH})_{2}$ sebanyak $1028 \mathrm{gr}$ dalam bentuk pasta atau endapan batu kapur. 
Variabel yang dipakai dalam melakukan penelitian ini meliputi : variabel tetap : perbandingan campuran kotoran kuda dengan air yakni $1: 1$, temperatur operasi (Top) : pada suhu ruang $\left(30^{\circ} \mathrm{C}\right)$. Sedangkan variabel berubah : laju aliran biogas : 5 liter/menit (pemurnian var 1), 10 liter/menit (pemurnian var 2) dan 15 liter/menit (pemurnian var 3), adsorben : $\mathrm{Ca}(\mathrm{OH})_{2}$ atau endapan batu kapur.

Penelitian dilanjutkan dengan proses adsorbsi biogas dengan adsorben $\mathrm{Ca}(\mathrm{OH})_{2}$ atau endapan batu kapur, selanjutnya direaksikan dengan $\mathrm{CO}_{2}$ maka akan terbentuk $\mathrm{CaCO}_{3}$ dan $\mathrm{H}_{2} \mathrm{O}$. Berikutnya variabel yang akan diamati adalah pengaruh laju aliran biogas terhadap $\mathrm{CO}_{2}$ yang terserap dan $\mathrm{CH}_{4}$ yang dihasilkan. Adsorbsi $\mathrm{CO}_{2}$ dilakukan dengan cara mengalirkan biogas melalui berbagai variasi laju aliran ke dalam $\mathrm{Ca}(\mathrm{OH})_{2}$. Biogas dan $\mathrm{Ca}(\mathrm{OH})_{2}$ akan saling bersinggungan dan proses reaksi kimia akan berlangsung. Setiap selang waktu 2 menit gas yang keluar adsorber dideteksi dengan biogas tester untuk dianalisa $\mathrm{CO}_{2}$ yang terserap dan $\mathrm{CH}_{4}$ yang dihasilkan. Adapun rangkaian alat uji pemurnian biogas adalah sebagai berikut,

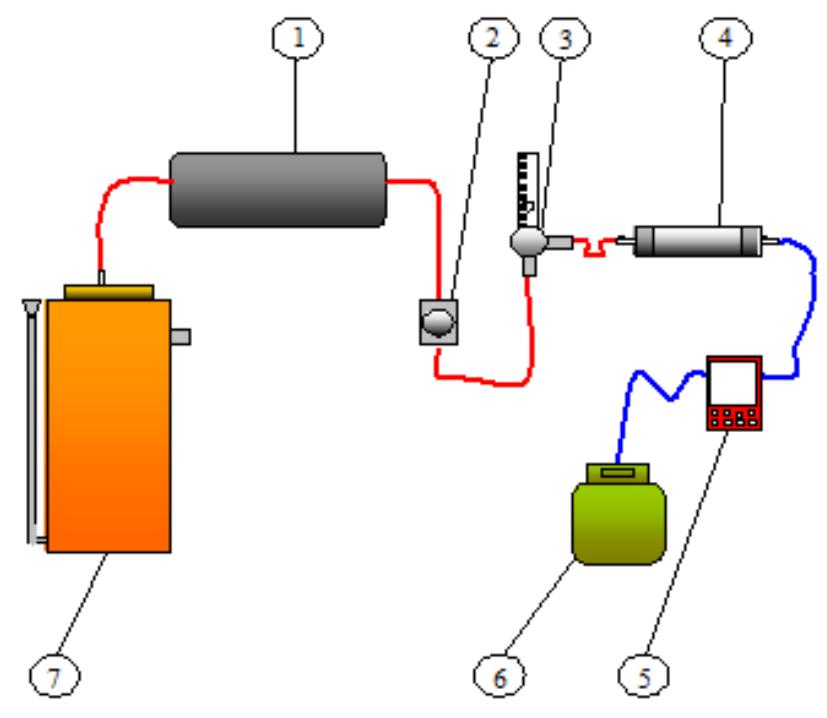

Gambar 2. Rangkaian alat pengujian pemurnian biogas. 1. tempat pengumpul biogas, 2. pompa vakum, 3. flowmeter, 4. adsorber, 5. biogas tester (type. ATEX Directive 94/9/EC), 6. tabung biogas yang telah termurnikan, 7. digester. berikut,

Adapun spesifikasi alat yang digunakan dalam penelitian ini dapat dilihat pada tabel 1 sebagai

\begin{tabular}{ll} 
& Tabel 1. Alat dan bahan \\
\hline Nama & Spesifikasi \\
\hline Digester & 900 liter \\
Pompa vacum & $1 / 4 \mathrm{PK}$ \\
Flowmeter & $3-15$ liter/menit \\
Adsorber & Berbentuk pipa dengan panjang $30 \mathrm{~cm}$ dan diameter $5 \mathrm{~cm}$ \\
Biogas tester & Type ATEX directive 94/9/EC \\
Tabung LPG & $3 \mathrm{~kg}$ \\
\hline
\end{tabular}

\section{HASIL DAN PEMBAHASAN}

Hasil penelitian menunjukkan bahwa pada biogas murni kandungan gas metan sebesar $49,5 \%$ seperti yang diperlihatkan pada gambar 3. Hal ini terjadi lebih dikarenakan masih banyaknya pengotor yang terkandung dalam biogas diantaranya gas $\mathrm{CO}_{2}$ dan gas lainnya. Sehingga menyebabkan nilai kalor yang dihasilkan masih rendah dan kualitas nyala api masih belum optimal. Pada penelitian ini penurunan kadar $\mathrm{CO}_{2}$ dilakukan dengan melewatkan biogas ke dalam $\mathrm{Ca}(\mathrm{OH})_{2}$ dengan laju aliran biogas yang divariasikan sehingga terjadi proses adsorbsi. Gas $\mathrm{CO}_{2}$ langsung bereaksi dengan $\mathrm{Ca}(\mathrm{OH})_{2}$ sedangkan $\mathrm{CH}_{4}$ tidak. Pada gambar 4 menunjukkan bahwa dengan seiring lamanya waktu 
proses adsorbsi maka semakin bagus kualitas biogas yang dihasilkan, hal ini ditandai dengan prosentase kadar gas $\mathrm{CH}_{4}$ semakin meningkat. Keadaan ini bisa terjadi dikarenakan semakin banyak kadar gas $\mathrm{CO}_{2}$ yang terserap dalam adsorben.

Pada proses pemurnian dengan laju aliran biogas yakni 5 liter/menit yang dilewatkan ke dalam $\mathrm{Ca}(\mathrm{OH})_{2}$, diperoleh data untuk kadar gas metan sebesar $76,2 \%$ sedangkan gas $\mathrm{CO}_{2}$ sudah tidak ada, hal ini menunjukkan bahwa biogas yang diperoleh sudah terbebas dari kadar gas karbon dioksida. Pada laju aliran biogas 10 liter/menit didapatkan biogas dengan kadar gas metan sebesar $91 \%$ dan gas karbon dioksida sudah tidak ada. Sedangkan untuk laju aliran biogas 15 liter/menit menunjukkan bahwa kadar gas metan sebesar $72 \%$ (gambar 3) sedangkan kadar gas karbon dioksida sudah terserap sempurna oleh $\mathrm{Ca}(\mathrm{OH})_{2}$.

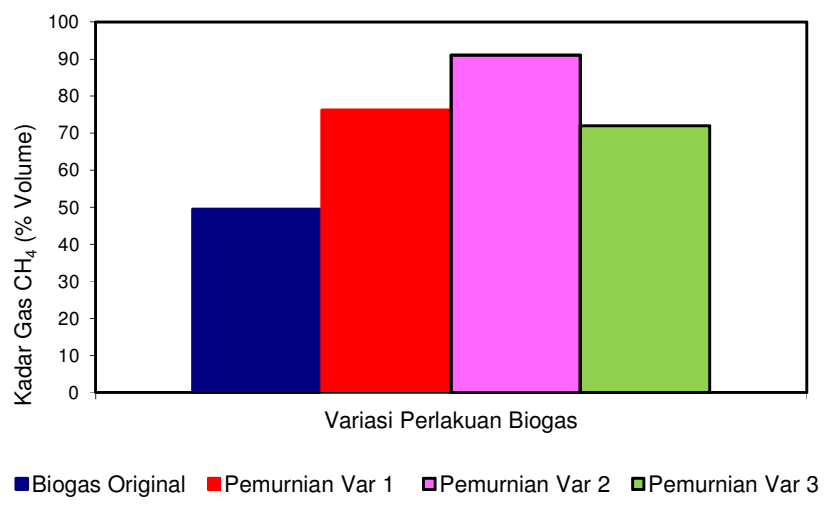

Gambar 3. Hubungan variasi perlakuan biogas dengan konsentrasi kadar gas $\mathrm{CH}_{4}$ dalam biogas.

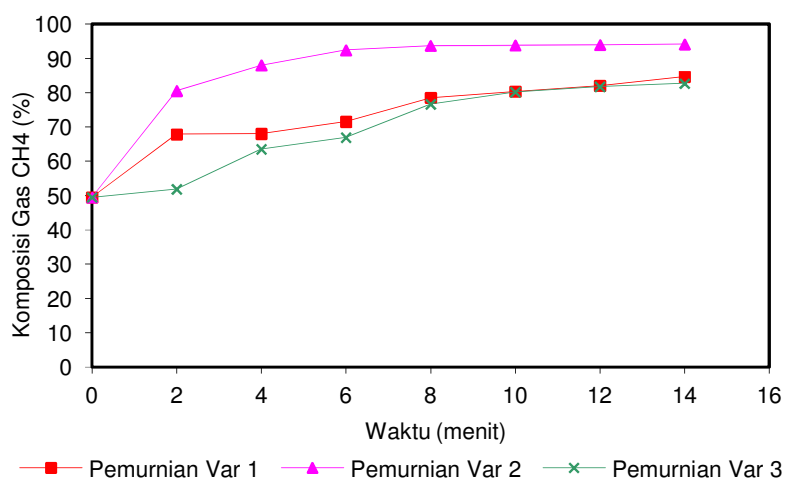

Gambar 4. Hubungan waktu pemurnian dengan konsentrasi kadar gas $\mathrm{CH}_{4}$ dalam biogas.

Pengaruh laju aliran biogas yang dilewatkan ke dalam adsorben memberikan hasil perbedaan yang cukup siknifikan. Seperti terlihat pada gambar 4 menunjukkan bahwa semakin tinggi laju aliran biogas yang melewati adsorben maka kemampuan adsorben menjadi kurang optimal, hal ini dikarenakan lamanya biogas bereaksi dengan $\mathrm{Ca}(\mathrm{OH})_{2}$ menjadi semakin singkat sehingga hanya sebagian kecil CO2 yang mampu diserap oleh adsorben.

Pada gambar 4 menunjukkan terjadi kenaikkan konsentrasi kadar gas metan yang terkandung di dalam biogas seiring dengan lamanya waktu proses pemurnian akan tetapi pada waktu tertentu akan terjadi dimana $\mathrm{Ca}(\mathrm{OH})_{2}$ sudah mengalami titik jenuh sedangkan kadar gas karbon dioksida yang bisa terserap sudah mengalami ambang batas. Pada kondisi tertentu kualitas biogas sudah tidak bagus lagi atau dengan kata lain sudah kembali seperti sedia kala yakni pada kondisi biogas sebelum dimurnikan. Hal ini hampir terjadi pada semua perlakuan baik pada laju aliran biogas 5 liter/menit, 10 liter/menit maupun pada 15 liter/menit.

Gambar 5 menunjukkan bahwa kadar $\mathrm{CO}_{2}$ di dalam biogas yang belum dimurnikan masih besar yakni sebesar $49,7 \%$ seperti yang diperlihatkan pada gambar 5 . Hal ini menyebabkan nilai kalor yang dihasilkan masih rendah sehingga kualitas nyala api biogas masih belum optimal. Untuk menurunkan 
kadar $\mathrm{CO}_{2}$ tersebut dilakukan dengan melewatkan biogas ke dalam $\mathrm{Ca}(\mathrm{OH})_{2}$ dengan laju aliran biogas yang divariasikan sehingga terjadi proses adsorbsi. Gas $\mathrm{CO}_{2}$ langsung bereaksi dengan $\mathrm{Ca}(\mathrm{OH})_{2}$ sedangkan $\mathrm{CH}_{4}$ tidak. Dengan berkurangmya konsentrasi $\mathrm{CO}_{2}$ sebagai akibat reaksi dengan $\mathrm{Ca}(\mathrm{OH})_{2}$, maka perbandingan konsentrasi $\mathrm{CH}_{4}$ dengan $\mathrm{CO}_{2}$ menjadi lebih besar untuk konsentrasi $\mathrm{CH}_{4}$.

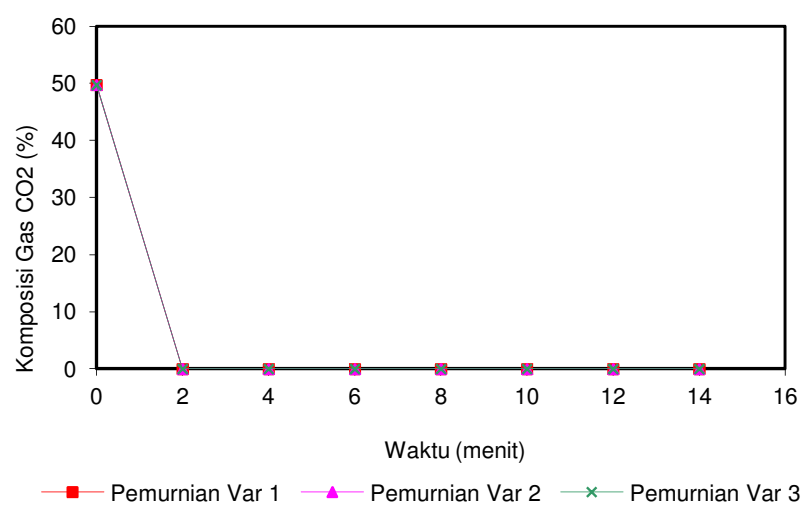

Gambar 5. Hubungan waktu pemurnian dengan konsentrasi kadar gas $\mathrm{CO}_{2}$ dalam biogas

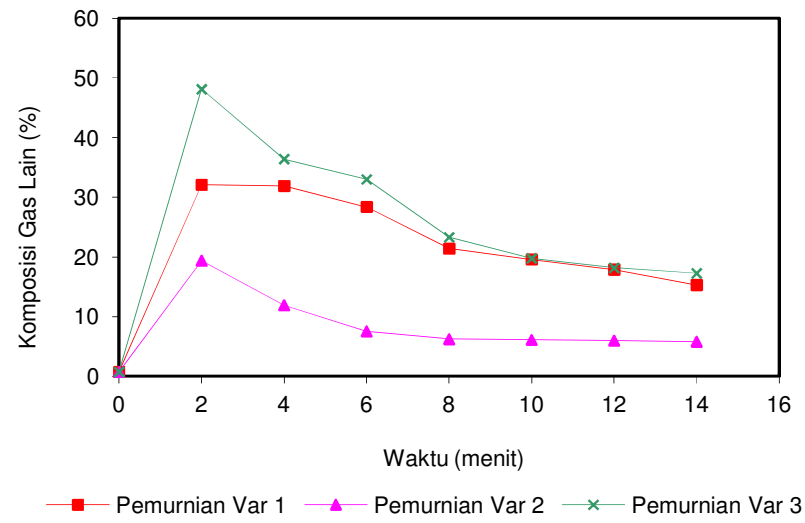

Gambar 6. Hubungan waktu pemurnian dengan konsentrasi kadar gas lain dalam biogas

Berdasarkan hasil penelitian menunjukkan bahwa konsentrasi gas metan terbesar didapat pada laju aliran gas 10 liter/menit, hal ini menunjukkan bahwa reaksi antara gas karbon dioksida dengan kalsium hidroksida terjadi secara sempurna, sehingga gas $\mathrm{CO}_{2}$ yang terkandung dalam biogas sudah tidak ada serta tidak menimbulkan kenaikan pada konsentrasi gas lain. Sedangkan untuk laju aliran biogas 5 liter/menit reaksi yang terjadi tidak optimal, hal ini dikarenakan pola reaksi yang terjadi hanya sebatas dimana gas itu mengalir dan kecenderungan pergerakan biogas laminer. Pada laju aliran biogas 15 liter/menit reaksi kimia yang terjadi semakin tidak optimal, hal ini dikarenakan waktu yang diperlukan untuk bersentuhannya antara molekul-molekul gas karbon dioksida dengan $\mathrm{Ca}(\mathrm{OH})_{2}$ semakin pendek. Meskipun gas $\mathrm{CO}_{2}$ telah terserap sempurna atau dengan kata lain biogas yang diperoleh sudah tidak mengandung gas karbon dioksida, akan tetapi menimbulkan pengaruh pada terbentuknya gas lain yang semakin banyak (gambar 6 ).

Hasil penelitian yang telah dilakukan oleh peneliti sebelumnya menunjukan bahwa penggunaan Zeolit zeochem 4A dapat mengadsorpsi $\mathrm{CO}_{2}$ sebanyak $18,70 \%$ (Apriyanti, 2012). Sedangkan penggunaan zeolit alam untuk memurnikan biogas dari $\mathrm{CO}_{2}, \mathrm{CO}_{2}$ yang disisihkan maksimal sebesar $87,041 \%$. Kandungan $\mathrm{CH}_{4}$ dalam biogas meningkat sebesar $37,375 \%$ setelah dimurnikan (Listyowati dkk., 2012). Pemurnian biogas dari $\mathrm{CO}_{2}$ dengan menggunakan karbon aktif yang berasal dari cangkang sawit yang dibandingkan dengan karbon aktif komersial. Peningkatan kadar $\mathrm{CH}_{4}$ sebesar $7 \%$ dan penurunan kadar $\mathrm{CO}_{2}$ sebesar $6,1 \%$ dengan menggunakan karbon aktif dari cangkang kelapa sawit, sedangkan karbon aktif komersial meningkatkan kadar $\mathrm{CH}_{4}$ sebesar $11,5 \%$ dan menurunkan kadar $\mathrm{CO}_{2}$ sebesar $12,9 \%$ (Widyastuti dkk., 2013). Pemurnian biogas dengan memanfaatkan adsorben $\mathrm{Ca}(\mathrm{OH})_{2}$ atau endapan batu kapur menghasilkan Konsentrasi gas metan 
$\left(\mathrm{CH}_{4}\right)$ terbesar didapat pada laju aliran biogas 10 liter/menit sebesar $91 \%$. Sedangkan konsentrasi gas karbon dioksida terserap sempurna yakni $100 \%$ untuk semua variasi laju aliran biogas. Jika dibandingkan dengan adsorben Zeolit zeochem 4A, karbon aktif dari cangkang sawit dan zeolit alam maka penggunaan adsorben endapan batu kapur didapatkan hasil kualitas biogas yang jauh lebih baik baik ditinjau dari kadar $\mathrm{CO}_{2}$ maupun kadar $\mathrm{CH}_{4}$.

\section{KESIMPULAN}

Hasil penelitian menunjukkan biogas yang belum dimurnikan mengandung kadar gas metan sebesar $49,7 \%$. Setelah dilakukan pemurnian dengan menggunakan adsorben endapan batu kapur $\left(\mathrm{Ca}(\mathrm{OH})_{2}\right)$ konsentrasi gas metan $\left(\mathrm{CH}_{4}\right)$ terbesar didapat pada laju aliran biogas 10 liter/menit sebesar $91 \%$. Sedangkan konsentrasi gas karbon dioksida terserap sempurna yakni $100 \%$ untuk semua variasi laju aliran biogas. Jika dibandingkan dengan adsorben Zeolit zeochem 4A, karbon aktif dari cangkang sawit dan zeolit alam maka penggunaan adsorben endapan batu kapur didapatkan hasil kualitas biogas yang jauh lebih baik baik ditinjau dari kadar $\mathrm{CO}_{2}$ maupun kadar $\mathrm{CH}_{4}$.

\section{DAFTAR NOTASI}

Pemurnian var 1

Pemurnian var 2

Pemurnian var 3

\author{
: Laju aliran biogas 5 liter/menit \\ : Laju aliran biogas 10 liter/menit \\ : Laju aliran biogas 15 liter/menit
}

DAFTAR PUSTAKA

Alwathan, Mustafa, Thahir R., 2013, Pengurangan kadar $\mathrm{H}_{2} \mathrm{~S}$ dari biogas limbah cair rumah sakit dengan metode adsorpsi. Jurnal Konversi, 2(1), 1-6.

Apriyanti E., 2012, Adsorpsi $\mathrm{CO}_{2}$ menggunakan zeolit : aplikasi pada pemurnian biogas. Jurnal Universitas Pandanaran, 10(22), 81-91.

Denny W., Hamidi N., Trimandoko C., 2014, Purifikasi biogas dengan variasi ukuran dan massa zeolit terhadap kandungan $\mathrm{CH}_{4}$ dan $\mathrm{CO}_{2}$, Jurnal Rekayasa Mesin, 5(3), 27-32.

Harasimowicz M.P., Orluk G., Zakrzewska T., Chmielewski A.G., 2007, Application of polyimide membranes for biogas purification and enrichment, Journal of Hazardous Materials, 144, 698702.

Listyowati, Anggreini F.P., Wirakartika M., Juliastuti S.R., Hendrianie N., 2012, Penurunan kadar $\mathrm{CO}_{2}$ dan $\mathrm{H}_{2} \mathrm{~S}$ pada biogas dengan metode adsorpsi menggunakan zeolit alam. Jurnal Teknik Pomits, 1(1), 1-5.

Nadliriyah N., Triwikantoro, 2014, Pemurnian produk biogas dengan metode absorbsi menggunakan larutan $\mathrm{Ca}(\mathrm{OH})_{2}$, Jurnal Sains dan Seni POMITS, 3(2), 107-111.

Sutanto R., Alit I.B., Nurchayati, 2014, Analisa unjuk kerja motor bakar berbahan bakar biogas termurnikan berbasis absorber $\mathrm{Fe}_{2} \mathrm{O}_{3}$, Dinamika Teknik Mesin, 4(2), 83-87.

Widyastuti, Apria, Sitorus B., Jayuska A., 2013, Karbon aktif dari limbah cangkang sawit sebagai adsorben gas dalam biogas hasil fermentasi anaerobik sampah organik, JKK, 2(1), 30-33. 